their publications are invariably assisted in their deception. Fortunately in the Natural-History Museum a sharp look-out is kept for cases of this kind, and covers are always considered when a book is sent to the binders.

The book that I wish to call attention to is F. Moore's 'Lepidoptera Indica,' of which thirteen parts have already appeared, and of which the proper dates are the following :-

Pt. 1. pp. i-viii, 1-24, April 1890.

2. , 25-56, June 1890.

3. , $57-80, \quad$ Sept. 1890.

4. , 81-96, Nov. 1890.

5. , 97-112, Dec. 1890.

6. , 113-128, Feb. 1891. Not Aug. 1890, as stated in the signatures!

7. , 129-152, Aug. 1891. Not Aug. and Nov. 1890 and July 1891, as stated in the signatures!

8. „, 153-176, Oct. 1891. Not July 1891, as stated in the signatures!

9. „177-208, Jan. 1892. Not Aug. and Sept. 1891, as stated in the signatures!

10. „, 209-240, April 1892. Not Oct. 1891 and Jan. 1892, as stated in the signatures!

11. „, 241-272, Sept. 1892. NotJan., Mar., and Apr.1892, as stated in the signatures!

12. „273-310, Dec. 1892. Not May and June 1892, as stated in the signatures!

13. , 1-32, Jan. 1893. Not Aug. 1892, as stated in the signatures!

I do not know whether the author or the publisher is responsible for this deceptive dating; but it is to be hoped that neither Mr. Lovell Reeve nor Mr. Moore will any further indulge in such objectionable vagaries.

Natural-History Museum, Cromwell Road, S.W.

C. Davies Sherborn (Index gen. et spec. anim.).

Feb. 18, 1893.

Diffuse Pigmentation of the Epidermis of the Oyster due to prolonged exposure to the light: Regeneration of Shell and Loss of Adductor Muscle.

Prof. Ryder reported on behalf of Prof. R. C. Schiedt that oysters which had the right valve removed and exposed to the light in this condition, in a living state, for a fortnight or so, developed pigment over the whole of the epidermis of the exposed right mantle and on the upper exposed sides of the gills, so that the whole animal from this cause assumed a dark-brown colour. Animals so exposed not only attempted to reproduce the lost valve and hinge, but also partly succeeded in so doing, even re-establishing the insertion of the

Ann. \& Mag. N. Hist. Ser. 6. Vol. xi. 
diminutive pedal muscle upon the inner face of the imperfectly reproduced right valve, which was deformed owing to the lack of support of the right mantle, because of the removal of the original right valve. As a consequence the right mantle was rolled up at the edge, and this deformation of the mantle was reflected in the attempted regeneration of the lost right valve. The pigment developed during exposure to light in the mantle and gills in oysters with the right valve removed which were kept alive in the aquaria at Sea Isle City by Prof. Schiedt was wholly confined to the epidermis as it normally is at the mantle-border in the unmutilated animal in nature. The inference to be drawn from these facts is that the development of pigment in the mantle and gills was wholly and directly due to the abnormal and general stimulus of light over the exposed surface of the mantle and gills, due to remoral of the right valve, and that the mantle-border, the only pigmented portion of the animal, is pigmented because it is the only portion of the animal which is normally and constantly subjected to the stimulus of light.

Oysters which had the right valve removed were found to live perfectly well in the marine aquaria at Sea Isle, and would no doubt have survived till now had Prof. Schiedt been able to continue his experiments there. The most remarkable results obtained as a consequence of these experiments were that the adductor muscle was soon attacked by bacteria and destroyed by putrefaction, while the great ganglion underlying it remained uninjured. The pericardiac cavity was also torn open, exposing the heart completely, in some instances. In these cases the heart continued to beat and propel the blood through the other organs of the body as if nothing untoward had happened. The maximum rate of pulsation of the heart noted was 52 per minute, which is much greater than the rate hitherto reported.

The anus was also retracted into a new and more anterior position, owing to the loss of support which it had suffered in consequence of the sloughing away of the adductor muscle. Whether the adductor muscle thus sloughed away would ultimately be reproduced was not determined, since the experiments were interrupted before the animals had time to present evidence of such regeneration of the lost muscles.

These experiments open up a most suggestive line of investigation upon other univalve and bivalve mollusca, viz.: experimental researches as to the effect of removing the valves and exposing them to the light. Many other species, both marine and freshwater, might obviously be experimented upon with very instructive results as respects the questions raised by the present communication.-Proc. Acad. Nat. Sci. Philad. Nov. 15, 1892.

\section{The Hermaphroditism and Viviparity of the Oysters of the North-west coast of the United States.}

Prof. J. A. Ryder also reported on behalf of Prof. R. C. Schiedt, of Franklin and Marshall College, Lancaster, Pa., the latter's discovery of the fact that the oysters native to the north-west coast 


\section{$2 \mathrm{BHL}$ Biodiversity Heritage Library}

1893. "Diffuse pigmentation of the epidermis of the oyster due to prolonged exposure to the light: Regeneration of shell and loss of adductor muscle." The Annals and magazine of natural history; zoology, botany, and geology 11, 261-262. https://doi.org/10.1080/00222939308677515.

View This Item Online: https://www.biodiversitylibrary.org/item/88432

DOI: https://doi.org/10.1080/00222939308677515

Permalink: https://www.biodiversitylibrary.org/partpdf/65282

\section{Holding Institution}

Smithsonian Libraries

\section{Sponsored by}

Smithsonian

\section{Copyright \& Reuse}

Copyright Status: Public domain. The BHL considers that this work is no longer under copyright protection.

This document was created from content at the Biodiversity Heritage Library, the world's largest open access digital library for biodiversity literature and archives. Visit BHL at https://www.biodiversitylibrary.org. 